\title{
ACUTE APPENDICITIS: DELAYED SURGERY DOES NOT INCREASE THE NUMBER OF POSTOPERATIVE COMPLICATIONS
}

\author{
Romualdas Riauka $^{1}$, Povilas Ignatavičius ${ }^{1}$, Žygimantas Tverskis ${ }^{1}$, Žilvinas Dambrauskas ${ }^{1,2}$ \\ ${ }^{I}$ Department of Surgery, Lithuanian University of Health Sciences, \\ ${ }^{2}$ Department of Surgery and Laboratory of Surgical Gastroenterology, Institute for Digestive System \\ Research Lithuanian University of Health Sciences
}

Key words: acute appendicitis, appendectomy, surgery.

\begin{abstract}
Summary
Introduction. Historically appendicitis is tending to be operated as soon as possible to prevent future complications. Recent discussions show, that urgent operation does not always reduce the rate of postoperative complications. Immediate appendectomy can be delayed in some cases.

Methods. Retrospective, non-randomized, single center, cohort study was performed. During one-year period 167 consecutive patients diagnosed with acute appendicitis were included in the study. The study population was divided into two groups according to the time from the onset of the symptoms to the operation. Group I ( $\leq 24$ hours) - 74 patients and Group II ( $\geq 24$ hours) -93 patients. Primary (postoperative complications) and secondary (operating time, length of hospital stay and perforation rate at the final pathology report) endpoints were evaluated and compared. Results. There was no statistically significant difference in the rate of postoperative complications when comparing both groups. In Group I $-21.9 \%$ patients $(87.5 \%$ Grade I) and in Group II - $25.8 \%$ patients ( $83 \%$ Grade I) had postoperative complications. Operating time was similar between the groups (72.97 \pm 29.1 (Group I) vs 79.95 \pm 35.4 minutes (Group II)). Length of hospital stay was longer in Group II, but no statistically significant difference was found ( $2.85 \pm 2.3$ vs $3.34 \pm 4.88$ days accordingly). Perforation rate at the final pathology report was twice higher in Group II (8 (10.8\%) vs 17 (18.3\%)), but no statistically significant difference was found.

Conclusions. This study findings support earlier reports showing that delayed appendectomy is safe sur-
\end{abstract}

gical procedure without higher rate of postoperative complications and may be applied in certain cases.

\section{Introduction}

Acute appendicitis (AA) is one of the most common acute surgical pathologies, requiring urgent hospitalization and surgical care. Etiological factors of AA are still unknown and might be multifactorial. Dietary, genetic, infectious, immunological factors and luminal obstruction have all been addressed to cause inflammation of the appendix (1). Historically appendicitis is tending to be operated as soon as possible in order to prevent future complications. However, the concept of emergency appendectomy has been recently challenged by studies suggesting that conservative treatment could be possible in selected cases (2). Previous studies stated that delayed surgery was not associated with increased morbidity. However best postoperative outcomes are reported, when appendectomy is performed within 24 hours from presentation of symptoms (3-5).

The aim of this study: to evaluate the association between the time from the onset of the symptoms to appendectomy and its impact on the rate of postoperative complications, operating time, length of hospital stay and perforation rate at the final pathology report.

\section{Material and methods}

This was a retrospective non-randomized, single center, cohort study. Data collection was performed at the Department of Surgery, Lithuanian University of Health Sciences using specially developed and maintained database from 01-01-2014 to 31-12-2014. During this period 167 consecutive patients diagnosed with AA in which operation was performed and who met the inclusion criteria: (1) patients older than 18; (2) diagnosed with AA (diagnosis was confirmed by combining clinical examination, laboratory tests, 
ultrasound and in complicated cases - CT scan if needed); (3) performed operation; (4) diagnosis was confirmed by pathological examination, were included in the study. The study population was divided into two groups according to the time from the onset of the symptoms to the operation. Group I (time to the operation $\leq 24$ hours) consisted of 74 patients and Group II (time to the operation $\geq 24$ hours) - 93 patients. Primary (postoperative complications) and secondary (length of operation, length of hospital stay and perforation rate at the final pathology report) endpoints were evaluated and compared. The Kaunas Regional Biomedical Research Ethics Committee approved the study (protocol no. BEC-MF-768) and allowed the use of publicly unavailable database.

Surgical procedure. All operations were performed by surgeons on duty. Laparoscopic appendectomy was a preferable approach to treat acute appendicitis in our hospital, as all the surgeons on call perform elective laparoscopic surgery in their every day practice. Two hand-made endoloops were used to seal the base of the appendix. Open approach was chosen occasionally, considering the clinical situation. Conversion from laparoscopic to open surgery was an option if necessary. All patients received antibiotic prophylaxis by single injection of $1^{\text {st }}$ generation cephalosporin's before the operation.

Postoperative course. In case of non-perforated appendicitis patients were allowed to drink clear liquids post- operatively and advanced to regular diet as tolerated. Most patients were discharged within 24 to 48 hours of surgery. In case of perforated appendicitis postoperatively the patients were treated by $2^{\text {nd }}$ generation cephalosporin's (cefuroxime) and metronidazole. Postoperative complications were classified according to Clavien-Dindo grading system for the classification of surgical complications (Grade I - V) (6).

Statistical analysis. Statistical analysis was performed using SPSS 19.0 for Windows (SPSS Inc., Chicago, USA).The data are presented as mean \pm standard deviation or median and range. For comparison between groups, the Mann-Whitney test or Student's $t$ test was employed where appropriate. $\mathrm{P}<0.05$ was considered statistically significant.

\section{Results}

Two hundred seventeen patients with suspected AA were hospitalized at the Department of Surgery, Lithuanian University of Health Sciences from 01-01-2014 to 31-12-2014. Data of 167 patients who met the inclusion criteria were analyzed. In forty-nine patient's diagnosis of AA was not confirmed or the patients were treated conservatively and were excluded from the study. Comparison of demographic characteristics between two groups is shown in Table 1.There was no statistically significant difference in any of these characteristics except "Time from onset of symptoms to the operation". Average time from the onset of symptoms to the operation in Group I was $16,13 \pm 5,46$ hours while in Group II it reached 44,98 $\pm 22,74$ hours.

This difference is explained by the division of the patients into two groups. The mean operation time in Group I was $72,97 \pm 29,11$ minutes. Patients of Group II were operated longer - 79,95 $\pm 35,41$ minutes. However, there was no statistically significant difference in operation time between two Groups. There were also no significant differences in the ratio of open and laparoscopic appendectomies.The level of C-reactive protein (CRP) at the time of admission in Group II was significantly higher $(83,78 \pm 87,50)$ compared to Group I $(34,84 \pm 45,21(p<0,001))$ (Table 2). However, there was no significant difference between values of CRP in both Groups at the time of patient discharge. There was no statistically significant difference in white blood cells (WBC) count between the Groups both at the admission and at the discharge (Table 2).Phlegmonous appendicitis dominated in both groups at the final pathological examination $(44(59,5 \%)$ vs. $48(51,6 \%))$. Perforation rate at the final pathology report was twice higher in Group II (8 (10.8\%) vs $17(18.3 \%))$, but no statistically significant difference was found. There was no statistically significant difference in the rate of postoperative complications (Clavien-Dindo grading system for the classification of surgical complications) when comparing both groups. In Group I - 21.9\% patients (87.5\% Grade I) and in Group II - 25.8\% patients (83\% Grade I) had minor postoperative complications.

Patients in Group II stayed in hospital longer than patients in Group I (2.85 2.3 vs $3.34 \pm 4.88$ accordingly), but no statistically significant difference was found.None of the patients in Group I died during hospital stay while death occurred in 1 patient $(1,1 \%)$ in Group II(patient with perforated appendicitis, peritonitis and chronic renal insufficiency) (Table 2).

\section{Discussion}

For many years' immediate appendectomy was the gold standard treatment for AA.However, in case of personnel shortage and limited hospital resources there may be a need to postpone the surgery for several hours. This concept is supported by our study showing that the timing of appendectomy could be safely delayed for several hours without increase of the number of postoperative complications.

Recent studies showed, that in some selected cases patients with AA could be treated conservatively, avoiding operation and associated complications. Conservative treatment could be alternative way of treatment 
for patients with high risk of surgery related morbidity.

Sallinen et al. in his recent meta-analysis showed, that antibiotic therapy might be a possible alternative to urgent operation. One of the major advantages of conservative treatment is lower number of minor and major complications. However, the recurrence rate in the first year was $23 \%$. In conclusion, this study stated, that for patients with acute uncomplicated appendicitis, who are averse of operation initial conservative antibacterial treatment is an option. The choice of medical versus surgical management in patients with clearly uncomplicated appendicitis is value- and preference-dependent (2). Controversial results were presented in the review by Rocha et al. Antibiotic therapy alone was associated with shorter pain duration, lower expenses and quicker return to work, but also with lower treatment success rate and high readmission rate. The authors concluded that conservative treatment of uncomplicated AA cannot be routinely suggested (7). Positive results of conservative treatment are showed in the NOTA study(8).Antibiotic therapy (amoxicillin/clavulanate) alone can reduce surgical risks, rates of unnecessary appendectomies, length of in-hospital stay and overall treatment costs. Out of 159 patients, treated with amoxicillin/clavulanate, only 22 patients developed recurrences and needed to be operated during 2 years follow up period.

Value of antibiotic treatment alone for acute inflammation of the appendix remains questionable and optimal way of treatment for each patient should be considered individually. The connection between time to operation and perforation rate is also a long-discussed topic. Some authors theorize that perforated and non-perforated AA could have different patterns and pathological processes (12). Drake et al. concluded that perforation rate was not associated with longer hospital stay prior appendectomy (13). In our study, there were no statistically significant differences in complication

Table 1. Patients' and procedure characteristics

\begin{tabular}{|l|c|c|c|}
\hline & $\begin{array}{c}\text { Group I, } \\
\mathbf{n}=\mathbf{7 4}\end{array}$ & $\begin{array}{c}\text { Group II, } \\
\mathbf{n = 9 3}\end{array}$ & $\mathbf{p}$ \\
\hline Male & $41(55.4 \%)$ & $41(44.1 \%)$ & 0,419 \\
\hline Female & $33(44.6 \%)$ & $52(55.9 \%)$ & 0,422 \\
\hline Age (years) & $34.47 \pm 15.33$ & $38.10 \pm 17.99$ & 0,170 \\
\hline $\begin{array}{l}\text { Time from onset of } \\
\text { symptoms to the opera- } \\
\text { tion (hours) }\end{array}$ & $16.13 \pm 5.46$ & $44.98 \pm 22.74$ & 0,000 \\
\hline Procedure & & & \\
\hline Open operation & $7(9.5 \%)$ & $10(10.8 \%)$ & 1,000 \\
\hline Laparoscopic operation & $67(90.5 \%)$ & $83(89.2 \%)$ & 1,000 \\
\hline Conversion & $1(1.4 \%)$ & $3(3.2 \%)$ & 0,632 \\
\hline Operation time (min) & $72.97 \pm 29.11$ & $79.95 \pm 35.41$ & 0,174 \\
\hline
\end{tabular}

rates in early versus delayed appendectomy groups, however the number of perforations were twice as high, and the length of hospital stay longer in delayed appendectomy group.

Some studies stated different opinion about safety of delayed appendectomy (14-17). Ditillo et al. found that number of postoperative complications and risk of perforation increases in time for patients diagnosed with AA, therefore, delayed appendectomy is unsafe(14). Slightly different findings were reported by Teixeira et al. The data showed that delayed appendectomy did not increased risk of perforation but increased risk of surgical site infection(15). Study by Giraudo et al. revealed that performing appendectomy within 24 hours from presentation does not increase the length of hospital stay or rate of complications. In opposite to our findings, this study showed that performing appendectomy after 24 hours from the onset of symptoms increases the rate of complications (16). In the retrospective study Eko et al. found no connection between higher risk of complications and timing of surgery, however, delayed appendectomy was associated with increased hospital stay (17).

In our study we haven't found statistically significant differences between early and delayed appendectomy Groups, although lower rate of complications, perforations, shorter hospital stay and better laboratory test values were recorded in early appendectomy Group.

Appendectomy remains the standard of care for most patients with AA for the following reasons: (1) the subset of patients least likely to fail initial non-operative management

Table 2. Postoperative course and outcomes

a - According to Clavien-Dindo grading system for the classification of surgical complications

\begin{tabular}{|l|c|c|c|}
\hline & $\begin{array}{c}\text { Group I, } \\
\mathbf{n}=\mathbf{7 4}\end{array}$ & $\begin{array}{c}\text { Group II, } \\
\mathbf{n}=\mathbf{9 3}\end{array}$ & $\mathbf{p}$ \\
\hline Blood tests & & & \\
\hline WBC count before operation & $13.67 \pm 3.49$ & $14.78 \pm 6.19$ & 0,304 \\
\hline WBC count after operation & $8.22 \pm 2.54$ & $7.70 \pm 2.04$ & 0,579 \\
\hline CRP count before operation & $34.84 \pm 45.21$ & $83.78 \pm 87.50$ & 0,001 \\
\hline CRP count after operation & $44.10 \pm 22.53$ & $63.30 \pm 42.96$ & 0,131 \\
\hline Final pathological report & & & \\
\hline Catarrhal appendicitis & $4(5.4 \%)$ & $7(7.5 \%)$ & 0,758 \\
\hline Phlegmonous appendicitis & $44(59.5 \%)$ & $48(51.6 \%)$ & 0,604 \\
\hline Gangrenous appendicitis & $26(35.1 \%)$ & $38(40.8 \%)$ & 0,658 \\
\hline Perforation rate & $8(10.8 \%)$ & $17(18.3 \%)$ & 0,284 \\
\hline Complications ${ }^{\mathbf{a}}$ & $16(21.6 \%)$ & $24(25.8 \%)$ & 0,723 \\
\hline I & $14(87.5 \%)$ & $20(83 \%)$ & 1,000 \\
\hline II & - & - & - \\
\hline III & $2(12.5 \%)$ & $3(12.5 \%)$ & 1,000 \\
\hline IV & - & - & - \\
\hline V & $0(0 \%)$ & $1(4.5 \%)$ & 1,000 \\
\hline Mortality & $0(0 \%)$ & $1(1.1 \%)$ & 1,000 \\
\hline Hospital stay (days) & $2.85 \pm 2.30$ & $3.34 \pm 4.67$ & 0,407 \\
\hline
\end{tabular}


has not been definitively determined, (2) appendectomy can generally be performed with low morbidity and very low mortality, (3) preoperative abdominal CT interpreted as uncomplicated appendicitis cannot exclude the possibility of complicated disease (18).

\section{Conclusions}

With significantly higher efficacy and low complication rates, appendectomy remains the most effective treatment for patients with uncomplicated acute appendicitis.Antibiotics-first strategy for uncomplicated acute appendicitis in adults is associated with increased rates of perforations and peritonitis at surgery in some cases and still needs to be developed (19). Our data supports the studies showing that early appendectomy is safe surgical procedure associated with shorter operating times, shorter length of hospital stay, and lower rate of perforations. The subgroups of patients with uncomplicated acute appendicitis where antibiotics and the delayed surgery can be more effective, should still be more accurately identified in the future studies. However, our findings suggest that occasionally the timing of appendectomy could be safely delayed within the window of few hours by the responsible surgeon depending on the available personnel and hospital resources (Table 1).

\section{Conflict of interest}

The authors declare no conflict of interest.

\section{References}

1. Humes DJ, Simpson J. Acute appendicitis. BMJ Br Med J [Internet] 2006; 333(7567):530-4. Available from: http://www. ncbi.nlm.nih.gov/pmc/articles/PMC1562475/

2. Sallinen V, Akl EA, You JJ, Agarwal A, Shoucair S, Vandvik PO. et al. Meta-analysis of antibiotics versus appendectomy for non-perforated acute appendicitis. Br J Surg [Internet]. 2016;103(6):656-67.

https://doi.org/10.1002/bjs.10147

3. Varadhan KK, Humes DJ, Neal KR, Lobo DN. Antibiotic therapy versus appendectomy for acute appendicitis: a metaanalysis. World J Surg [Internet]. 2010;34(2):199-209.

https://doi.org/10.1007/s00268-009-0343-5

4. Liu K, Fogg L. Use of antibiotics alone for treatment of uncomplicated acute appendicitis: a systematic review and meta-analysis. Surgery [Internet]. 2011;150(4):673-83.

https://doi.org/10.1016/j.surg.2011.08.018

5. Nagpal NavalKishor, Sharma Niraj, Curras Ernesto, Cosgrove John Morgan, Farkas Daniel T KU. Delaying an appendectomy: is it safe? Am Surg 2012;78(8):897-900.

6. Clavien PA, Barkun J, de Oliveira ML, Vauthey JN, Dindo D, Schulick RD. et al. The Clavien-Dindo classification of surgical complications: five-year experience. Ann Surg [Internet]
2009; 250(2):187-96. Available from: http://journals.lww.com/ annalsofsurgery/Fulltext/2009/08000/The_Clavien_Dindo_Cla ssification_of_Surgical.2.aspx

7. Rocha LL, Rossi FMB, Pessoa CMS, Campos FND, Pires CEF, Steinman M. Antibiotics alone versus appendectomy to treat uncomplicated acute appendicitis in adults: what do meta-analyses say? World J Emerg Surg [Internet] 2015;10:51. Available from: http:/www.ncbi.nlm.nih.gov/pmc/articles/ PMC4628279/

https://doi.org/10.1186/s13017-015-0046-1

8. Di Saverio S, Sibilio A, Giorgini E, Biscardi A, Villani S, Coccolini F. et al. The NOTA Study (Non Operative Treatment for Acute Appendicitis). Ann Surg [Internet] 2014 Jul [cited 2017 Dec 20];260(1):109-17. Available from: http://www.ncbi.nlm. nih.gov/pubmed/24646528

9. Boomer LA, Cooper JN, Deans KJ, Minneci PC, Leonhart K, Diefenbach KA. et al. Does delay in appendectomy affect surgical site infection in children with appendicitis? J Pediatr Surg [Internet] 2014;49(6):1026-9. Available from: http://www. sciencedirect.com/science/article/pii/S0022346814000530 https://doi.org/10.1016/j.jpedsurg.2014.01.044

10. Chen C-C, Ting C-T, Tsai M-J, Hsu W-C, Chen P-C, Lee M-D. et al. Appendectomy timing: will delayed surgery increase the complications? J Chinese Med Assoc [Internet] 2015;78(7):395-9. Available from: http://www.sciencedirect. com/science/article/pii/S172649011500088X https://doi.org/10.1016/j.jcma.2015.04.001

11. Shin CS, Roh YN, Kim J Il. Delayed appendectomy versus early appendectomy in the treatment of acute appendicitis: a retrospective study. World J Emerg Surg [Internet] 2014;9:8. Available from: http://www.ncbi.nlm.nih.gov/pmc/articles/ PMC3900735/

https://doi.org/10.1186/1749-7922-9-8

12. Andersson R, Hugander A, Thulin A, Nystrom PO, Olaison G. Indications for operation in suspected appendicitis and incidence of perforation. BMJ [Internet] 1994;308(6921):107-10. Available from: http://www.ncbi.nlm.nih.gov/pubmed/8298378 https://doi.org/10.1136/bmj.308.6921.107

13. Drake FT, Mottey NE, Farrokhi ET, Florence MG, Johnson MG, Mock C. et al. Time to appendectomy and risk of perforation in acute appendicitis. JAMA Surg [Internet] 2014;149(8):837-44. Available from: http:/www.ncbi.nlm.nih.gov/pmc/articles/PMC4160117/ https://doi.org/10.1001/jamasurg.2014.77

14. Ditillo MF, Dziura JD, Rabinovici R. Is it safe to delay appendectomy in adults with acute appendicitis? Ann Surg [Internet] 2006;244(5):656-60. Available from: http://www.ncbi.nlm.nih. gov/pmc/articles/PMC1856602/ https://doi.org/10.1097/01.sla.0000231726.53487.dd

15. Teixeira PG, Sivrikoz E, Inaba K, Talving P, Lam L, Demetriades D. Appendectomy timing: waiting until the next morning increases the risk of surgical site infections. Ann Surg [Internet] 2012;256(3):538-43. Available from: http://journals.lww.com/ 
annalsofsurgery/Fulltext/2012/09000/Appendectomy_Timing_

16. Giraudo G, Baracchi F, Pellegrino L, Dal Corso HM, Borghi F. Prompt or delayed appendectomy? Influence of timing of surgery for acute appendicitis. Surg Today [Internet] 2013;43(4):392-6. https://doi.org/10.1007/s00595-012-0250-5

17. Eko FN, Ryb GE, Drager L, Goldwater E, Wu JJ, Counihan TC. Ideal timing of surgery for acute uncomplicated appendicitis. NAm J Med Sci [Internet] 2013;5(1):22-7. Available from: http://www. ncbi.nlm.nih.gov/pmc/articles/PMC3560134/

https://doi.org/10.4103/1947-2714.106186

18. Smink D. Management of acute appendicitis in adults [Internet] Post TW (Ed), UpToDate, Waltham, MA: UpToDate; Available from: http:/www.uptodate.com/contents/management-of-acuteappendicitis-in-adults

19. Podda M, Cillara N, Di Saverio S, Lai A, Feroci F, Luridiana G. et al. Antibiotics-first strategy for uncomplicated acute appendicitis in adults is associated with increased rates of peritonitis at surgery. A systematic review with meta-analysis of randomized controlled trials comparing appendectomy and non-operative managem. Surg [Internet] 2017;15(5):303-14. Available from: http://linkinghub. elsevier.com/retrieve/pii/S1479666X17300562

\section{ATIDE்TA APENDEKTOMIJA NEDIDINA POOPERACINIŲ KOMPLIKACIJŲ DAŽNIO R.Riauka, P.Ignatavičius, Ž.Tverskis, Ž.Dambrauskas} racija.

Raktažodžiai: ūminis apendicitas, skubi apendektomija, ope-

Santrauka

Ivadas. Manoma, kad norint išvengti pooperacinių komplikacijų, ūminị apendicitą reikia operuoti kiek įmanoma skubiau. Tačiau naujausi moksliniai tyrimai rodo, kad skubi apendektomija ne visada susijusi su geresnemis pooperacinėmis baigtimis. Tam tikrais atvejais operaciją galima atideti.

Metodika. Atlikta retrospektyvinè pacientų, kuriems 2014 metais LSMUL KK Chirurgijos klinikoje atlikta apendektomija, ligos istorijų analizè. I tyrimą įtraukti 167 pacientai. Pacientai, pagal laiką tarp simptomų pradžios ir operacijos pradžios, suskirstyti i dvi grupes: I grupè - $<24$ valandos (74 pacientai), II grupé - $>24$ valandos (93 pacientai). Vertinta ir lyginta pacientų operacijos ir stacionarizavimo trukmè, pooperacinių komplikacijų dažnis, histologinių tyrimų rezultatai.

Rezultatai. Pooperacinių komplikacijų dažnis (Clavien-Dindo pooperaciniu komplikacijų skalè) tarp tiriamuju grupių (I grupė - 21,9 proc., II grupe - 25,8 proc.) statistiškai reikšmingai nesiskyrè ( $\mathrm{p}>0,05)$. Abiejose grupèse didžiają dalị komplikacijų sudarè Clavien-Dindo I laipsnio komplikacijos (I grupè - 87,5 proc., II grupè - 83 proc.). Operacijos trukmės statistiškai reikšmingai tarp I (72,97 $\pm 29,11$ minutès) ir II grupès (79,95 $\pm 35,41$ minutès) pacientų nesiskyrè $(p>0,05)$. Lovadienių skaičius II grupejje $(3,34 \pm 4,88)$ buvo ilgesnis nei I grupeje $(2,85 \pm 2,3)$, bet statistiškai reikšmingai nesiskyrè. Perforacijų dažnis galutiniame histologinio tyrimo atsakyme I grupeje (8 (10,8 proc.) buvo mažesnis nei II (17 (18,3 proc.), bet statistiškai reikšmingai nesiskyrè $(\mathrm{p}>0,05)$.

Išvados. Atidèta apendektomija - saugi procedūra, kurios pooperacinių komplikacijų dažnis nesiskiria nuo skubios apendektomijos. Tam tikrais atvejais apendektomija gali būti atidèta.

Adresas susirašinèti: povilas.ignatavicius@1smuni.lt

Gauta 2018-03-22 